\title{
Bacterial Profile of Urinary Tract Infections (UTI) in Benin: A Retrospective Study from 2003 to 2012 at Menontin's Hospital
}

\author{
Honoré Sourou Bankolé1, Victorien Dougnon ${ }^{*}$, Christian Johnson ${ }^{1}$, Gildas Hounmanou ${ }^{1}$, \\ Modupeola Alokolaro², Lamine Baba-Moussa ${ }^{3}$ \\ ${ }^{1}$ Research Laboratory in Applied Biology, Polytechnic School of Abomey-Calavi, University of \\ Abomey-Calavi, Cotonou, Benin \\ ${ }^{2}$ Department of Biotechnology, African University of Technology and Management, Campus of Gbegamey, \\ Cotonou, Benin \\ ${ }^{3}$ Laboratory of Biology and Molecular Typing in Microbiology, Faculty of Sciences and Techniques, \\ University of Abomey-Calavi, Cotonou, Benin \\ Email: *victorien88@hotmail.com
}

Received 19 May 2016; accepted 12 June 2016; published 15 June 2016

Copyright (C) 2016 by authors and Scientific Research Publishing Inc.

This work is licensed under the Creative Commons Attribution International License (CC BY).

http://creativecommons.org/licenses/by/4.0/

(c) (i) Open Access

\section{Abstract}

Urinary tract infections remain the most common bacterial infection in human population. They are also one of the most frequently occurring nosocomial infections, representing about $40 \%$ of all nosocomial bacterial infections world widely and associated with important medical and financial implications. This retrospective study aimed to establish the bacterial profile of UTIs in Benin. Therefore, reported data were collected from 2003 to 2012 at Menontin's Hospital in Cotonou and subjected to analyses. At the end of the study, fourteen different bacteria species were found to be associated with UTI cases in Benin. Escherichia coli was the most prevalent followed by Staphylococcus aureus. Results of the current study are helpful to the health care community of Benin in establishing the appropriate antibiotherapy for UTI patients' treatment with respect organisms into circulation.

\section{Keywords}

Bacteria, UTIs, Public Health

\footnotetext{
${ }^{*}$ Corresponding author.
}

How to cite this paper: Bankolé, H.S., Dougnon, V., Johnson, C., Hounmanou, G., Alokolaro, M. and Baba-Moussa, L. (2016) Bacterial Profile of Urinary Tract Infections (UTI) in Benin: A Retrospective Study from 2003 to 2012 at Menontin's Hospital. Open Journal of Medical Microbiology, 6, 53-58. http://dx.doi.org/10.4236/ojmm.2016.62008 


\section{Introduction}

Respiratory and urinary tract infections (UTI), are associated with the highest level of morbidity in mankind and are therefore of great public health concern. Urinary tract infections especially, remain the most common bacterial infection in human population and also one of the most frequently occurring nosocomial infections, representing about $40 \%$ of all nosocomial bacterial infections world widely [1]. Additionally, there are important medical and financial implications associated with UTIs. According to studies conducted by [2], the estimated annual cost of community-acquired UTI is significant. Besides, urinary tract infections are major causes of morbidity and mortality in the first 2 years of human life, in women and mostly in elders [3]. Moreover, UTIs are caused by numerous bacteria among which are Escherichia coli, Staphylococcus saprophyticus, Klebsiella spp., Proteus spp. or Enterobacter spp. [4]. Due to this wide variety of causative agents, the treatment of UTIs is sometimes inadequate. Thus, appropriate medication might not be given and this can easily lead to challenges such as antibiotic resistance among patients. In order to control the emergence of antimicrobial resistance among UTI patients, national and international surveillance programmes are necessary to monitor the bacterial profile of UTIs at every health care centre level so as to appropriately prescribe the needed drugs and avoid antimicrobial resistance.

The current study was therefore aiming at understanding the profile of bacteria that were associated with UTI cases in Benin mainly at Menontin hospital by underlining the most prevalent ones so as to assist health care decision makers in adequate treatment designing.

\section{Materials and Methods}

\subsection{Study Area}

This study was conducted at Menontin hospital, situated in Cotonou (Republic of Benin). It is a public hospital which provides medical care.

\subsection{Study Population}

Participants of this study comprised patients who came to the laboratory department of Menontin hospital with signs and symptoms of urinary tract infections from 2003 to 2012.

\subsection{Study Design}

This was a retrospective study conducted as an observational cross-sectional study design.

\subsection{Data Collection and Processing}

Data under this study were retrospectively collected with existing records of the laboratory. Briefly, bacteriological raw results that were recorded by the laboratory of Menontin Hospital from 2003 to 2012 from UTI patients were collected following the authorization of the Head of Laboratory and subjected to analyses. These data were thereafter entered into Microsoft Excel software for Window version 2013 whereby various computations and statistical analyses were carried out. Notably the different species of bacteria isolated during this period were sorted out. The proportion of isolation of each bacterium species was calculated per year in order to assess the most predominant species of each year. Comparisons were performed in order to find out the most prevalent bacterium isolated from patients with UTIs at Menontin hospital from 2003 to 2012. Results are presented as tables and graphs.

\section{Results}

\subsection{Profile of Bacteria Isolated from UTI Suspected Patients from 2003 to 2012 at Menontin Hospital}

As displayed by Table 1(a) and Table 1(b), there is a wide diversity of bacteria isolated from UTI suspected patients at Menontin Hospital. Overall, from 2003 to 2012, fourteen different bacteria species were isolated from 2703 patients with UTI symptoms, namely: Staphylococcus aureus (25.08\%), S. epidermidis (1.88\%), S. saprophyticus (0.96\%), Streptococcus D (14.24\%), Streptococcus B(1.03\%), Escherichia coli (36.07), Kleb- 
Table 1. (a) Profile of bacteria isolated, (b) frequency of bacteria isolated from UTI patients from 2003 to 2012 at Menontin Hospital.

(a)

\begin{tabular}{ccccccccccc}
\hline Years & 2003 & 2004 & 2005 & 2006 & 2007 & 2008 & 2009 & 2010 & 2011 & 2012 \\
Bacteria & 153 & 96 & 52 & 60 & 39 & 61 & 35 & 78 & 53 & 51 \\
\hline $\begin{array}{c}\text { Staphylococcus. aureus } \\
\text { Staphylococcus. epidermidis }\end{array}$ & 17 & 6 & 3 & 10 & 4 & 1 & 2 & 1 & 2 & 5 \\
Staphylococcus. saprophyticus & 1 & 1 & 3 & 0 & 2 & 1 & 7 & 6 & 6 & 0 \\
Streptococcus D & 54 & 34 & 19 & 24 & 37 & 42 & 50 & 43 & 32 & 50 \\
Streptococcus B & 13 & 3 & 5 & 2 & 0 & 1 & 1 & 3 & 0 & 1 \\
\hline
\end{tabular}

(b)

\begin{tabular}{ccccccccccc}
\hline Years & 2003 & 2004 & 2005 & 2006 & 2007 & 2008 & 2009 & 2010 & 2011 & 2012 \\
Bacteria & & & & & & & & & & \\
\hline Escherichia coli & 69 & 67 & 82 & 125 & 70 & 133 & 137 & 112 & 87 \\
Klebsiella spp. & 64 & 56 & 19 & 43 & 23 & 34 & 29 & 44 & 40 & 48 \\
Proteus spp. & 18 & 1 & 6 & 1 & 0 & 2 & 6 & 1 & 1 & 0 \\
Pseudomonas spp. & 10 & 3 & 6 & 5 & 5 & 4 & 2 & 7 & 7 & 4 \\
Enterobacter spp. & 7 & 2 & 3 & 0 & 2 & 5 & 6 & 2 & 1 & 2 \\
Acinetobacter spp. & 1 & 1 & 4 & 2 & 0 & 5 & 4 & 0 & 0 & 2 \\
Providencia spp. & 3 & 2 & 2 & 0 & 0 & 0 & 0 & 1 & 0 & 1 \\
Shigella spp. & 3 & 1 & 2 & 0 & 0 & 1 & 0 & 0 & 0 & 0 \\
Citrobacter spp. & 4 & 0 & 1 & 0 & 0 & 1 & 0 & 0 & 0 & 0
\end{tabular}

siella spp. (14.80\%), Proteus spp. (1.33\%), Pseudomonas spp. (1.96\%), Enterobacter spp. (1.11\%), Acinetobacter spp. (0.70\%), Providencia spp. (0.33\%), Shigella spp. (0.26\%) and Citrobacter spp. (0.22\%). Some of these bacteria were isolated at least once in each of the 10 years (Staphylococcus aureus, S. epidermidis, Streptococcus D, Escherichia coli, Klebsiella spp., and pseudomonas spp. ) while others were not consistently present every year.

Furthermore, out of the fourteen bacteria species isolated from UTI patients, 35.72\% (5/14) were Gram positive while the remaining 64.28\% (9/14) was constituted of Gram negative bacteria belonging to the family Enterobacteriacae among which 55.55\% (5/9) were coliform bacteria. Besides, bacteria that were isolated at Menontin hospital from 2003 to 2012 belong to groups of pathogens involved in either complicated or uncomplicated UTI cases.

\subsection{Evolution of the Predominant Bacteria overtime at Menontin Hospital from 2003 to 2012}

The results demonstrated a variation in isolates throughout the 10 years. For instance, the predominant organism in 2003 was Staphylococcus aureus (34.69\%) followed by E. coli (21.08\%) (Figure 1). Similar scenario was recorded in 2004 whereby Staphylococcus aureus came first with a proportion of 34.90\% preceding E. coli (25.09\%). Nevertheless, from 2005 to the end (2012), E. coli was the leading bacterium found in UTI patients' samples. As a matter of fact, results of 2012 for example showed a proportion of 34.66\% for E. coli followed by Staphylococcus aureus and Streptococcus D (20.32\% and 19.92\% respectively) (Figure 2). Moreover, E. coli, which occupied the second place in the previous years (2003-2004) became constantly the predominant and by far, the most prevalent bacterium isolated from UTI patients at Menontin hospital during the recent years (2005-2012) (Figure 3). More interestingly, for each of the last 8 years (2005 to 2012), while E. coli was the most prevalent isolate, Staphylococcus aureus remained its second from all the tested UTI patients. 


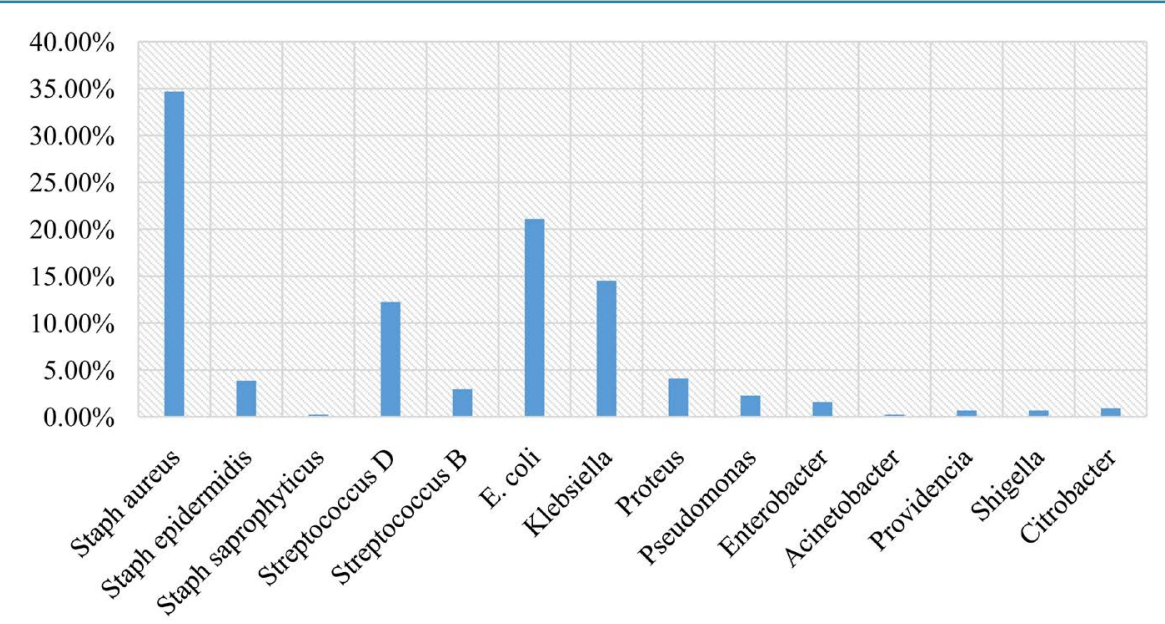

Figure 1. Frequency of bacteria isolated from UTI patients in 2003.

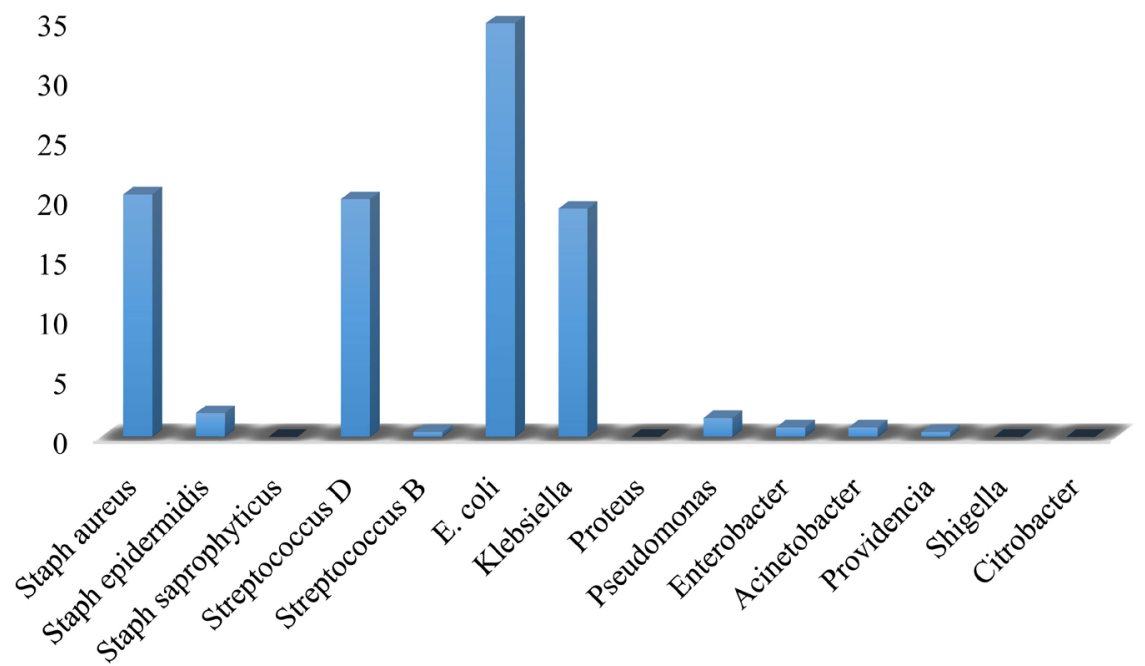

Figure 2. Frequency of bacteria isolated from UTI patients in 2012.

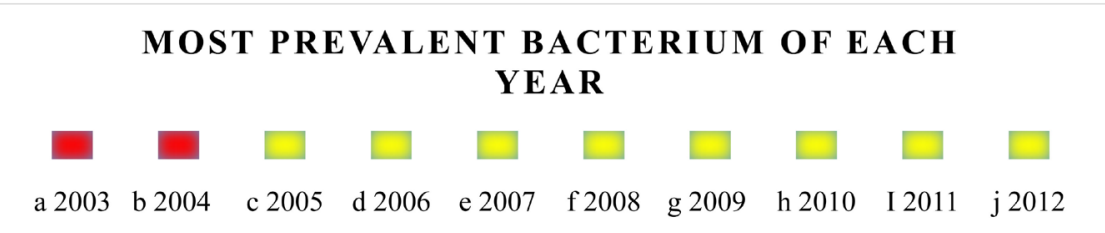

Legend: $\square$ Staphylococcus aureus

Figure 3. Predominant bacterium of each year, from 2003 to 2012.

\subsection{Most Prevalent Bacteria Isolated from UTI Patients at Menontin Hospital from 2003 to 2012}

Analyzing all the 10 years together, it comes out that the most prevent bacteria isolated at the laboratory during these 10 years period was: E. coli (36.07\%) followed by Staphylococcus aureus (25.08\%), Klebsiella spp. (14.80\%) and Streptococcus D (14.24\%) (Figure 4). 


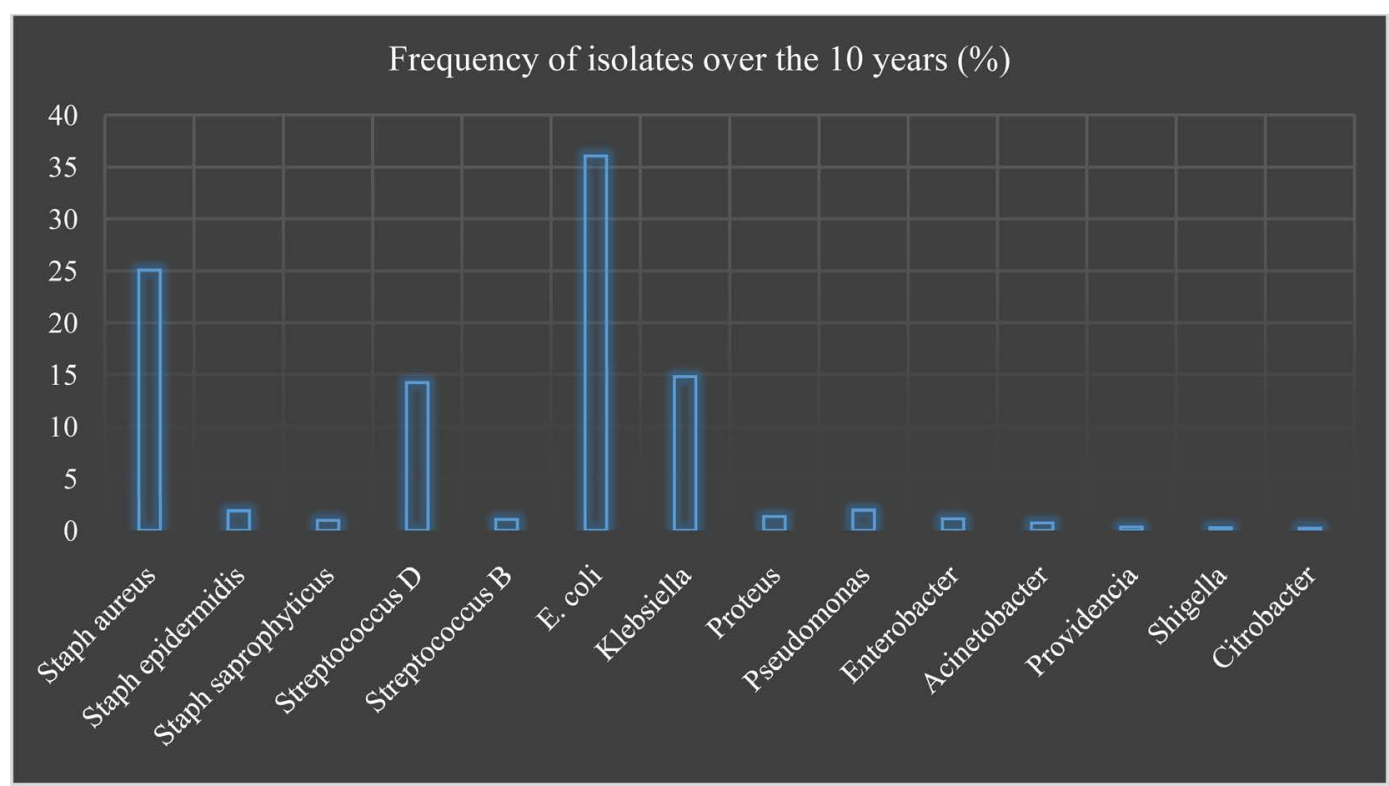

Figure 4. The most prevalent Bacterium isolated during the 10 years period.

\section{Discussion}

About fourteen bacteria species were recorded from bacteriological analyses conducted on UTI patients' samples at Menontin Hospital from 2003 to 2012. Different bacteria are therefore associated with UTI infections in Benin among which E. coli (36.07\%), Staphylococcus aureus (25.08\%), Klebsiella spp. (14.80\%) and Streptococcus D (14.24\%) seem to be the most common ones and were isolated throughout the 10 years period from at least 1 patient each year. Furthermore, out of the fourteen bacteria species isolated from UTI patients, 35.72\% (5/14) were Gram positive while the remaining $64.28 \%$ (9/14) was constituted of Gram negative bacteria belonging to the family Enterobacteriacae among which 55.55\% (5/9) were coliform bacteria. Besides, bacteria that were isolated at Menontin hospital from 2003 to 2012 belong to groups of pathogens involved in either complicated or uncomplicated UTI cases. The high prevalence of Gram-negative bacteria with E. coli as the predominant organism in this study is in agreement with previous reports [4] [5].

The predominance of enterobacteriacae mainly of E. coli in UTIs is in accordance with the physiopathology of UTI which is commonly upward associated with high colonization of the perineum by enterobacteria from the GI tract. Furthermore, [4] suggested that specific factors of the uropathogenicity of $E$. coli had an important role to play. In detail, E. coli possesses some pili capable of binding it up in the urinary epithelium and thus prevent its elimination by the urine. In terms of most prevalent bacteria, our results (E. coli 36.07\%) fit with other studies but seem to be lower. Reference [6] for example recorded up to $47 \%$ in there study. This could be probably due to the large variation of different species found in the current study. As it appeared in the results, Gramnegative bacilli were the pathogens most frequently associated with UTIs during the 10 years. However, Grampositive bacterial pathogens were isolated as well. They are commonly found in UTIs thanks to the lipoteichoic acid that they got in their cell wall and which is used as adherence factor to stay and survive in the urinary tract. According to [7] Staphylococcus saprophyticus and Streptococcus are the most isolated Gram positive bacteria of UTIs. The high prevalence of Staphylococcus aureus (25.08\%) being the most prevalent of the Gram positives in this study is not common [4] [5]. This new etiological pattern of UTIs could be due to the treatment given to UTI patients that mostly target other Gram positive bacteria such as Staphylococcus saprophyticus commonly isolated from UTI cases by neglecting Staphylococcus aureus and therefore enhance its survival and growth in patients. Such situation could be very threatening in the treatment of UTIs in case they are exclusively associated with $S$. aureus because of the emergence of its new strain highly resistant to antimicrobial agents and known as Methiciline Resistant S. aureus (MRSA).

With respect to studies conducted by [8], the etiology of UTI is also affected by underlying host factors that complicate UTI, such as age, diabetes, spinal cord injury, or catheterization. Consequently, complicated UTI has 
a more diverse etiology than uncomplicated UTI, and organisms that rarely cause disease in healthy patients can cause significant disease in hosts with anatomic, metabolic, or immunologic underlying disease.

\section{Conclusion}

Out of the 2703 UTI patients whose samples were analyzed at Menontin Hospital laboratory from 2003 to 2012, fourteen different bacteria species were isolated with $E$. coil being the most prevalent one. Surprisingly, S. $a u-$ reus, stayed as the second cause of UTI cases during these 10 years period. This could be a critical risk factor of emergence of MRSA from UTIs since. The study suggests therefore the establishment of a critical antibiogram of the most frequently isolated organism for appropriate use of antimicrobial agents in the treatment.

\section{References}

[1] Mahamat, A., Lavigne, J.P., Bouziges, N., Daurè, J.P. and Sotto, A. (2006) Antimicrobial Susceptibility of Proteus mirabilis Urinary Tract Isolates from 1999 to 2005 at Nîmes University Hospital. Pathologie Biologie, 54, 456-461. http://dx.doi.org/10.1016/j.patbio.2006.07.015

[2] Foxman, B. (2003) Epidemiology of Urinary Tract Infections: Incidence, Morbidity, and Economic Costs. Disease-aMonth, 49, 53-70. http://dx.doi.org/10.1067/mda.2003.7

[3] Lemort, M.L., Neuville, S., Medus, M., Gueudet, P., Saada, M., Aumaître, H. and Lecaillon, E. (2006) Comparative Susceptibility Evolution in Escherichia coli from Urinarytract Infections in Outpatients and Inpatients at Perpignan Hospital in 2002 and 2004. Pathologie Biologie, 54, 427-430. http://dx.doi.org/10.1016/j.patbio.2006.07.007

[4] Sekhsokh, Y., Chadli, M. and El Hamzaoui, S.A. (2008) Frequency and Antibiotic Susceptibility of Bacteria Identified in Urine. Médecine et Maladies Infectieuses, 38, 324-327. http://dx.doi.org/10.1016/j.medmal.2008.02.003

[5] Opoku, O.A.C. (2004) Urinary Tract Infections in African Infants. International Journal of Antimicrobial Agents, 24, 32-34. http://dx.doi.org/10.1016/j.ijantimicag.2004.02.007

[6] Daza, R., Gutiérrez, J. and Piédrola, G. (2001) Antibiotic Susceptibility of Bacterial Strains Isolated from Patients with Community-Acquired Urinary Tract Infections. International Journal of Antimicrobial Agents, 18, 211-215. http://dx.doi.org/10.1016/S0924-8579(01)00389-2

[7] Gaynes, R. and Edwards, J.R. (2005) Overview of Nosocomial Infections Caused by Gram-Negative Bacilli. Clinical Infectious Diseases, 41, 848-854. http://dx.doi.org/10.1086/432803

[8] Ronald, A. (2003) The Etiology of Urinary Tract Infection: Traditional and Emerging Pathogens. Disease-a-Month, 49, 71-82. http://dx.doi.org/10.1067/mda.2003.8 